POLITEIA
Politeia: Jurnal Ilmu Politik
Politeia: Jurnal Ilmu Politik, 10 (1) (2018): 44-51
ISSN 0216-9290 (Print), ISSN 2549-175X (Online)
Available online https://jurnal.usu.ac.id/index.php/politeia

\title{
Kemenangan Partai Partai Aceh pada Pemilihan Legeslatif 2009 di Kabupaten Aceh Tamiang 2009
}

\author{
Abdi Karya* \\ Departemen Ilmu Politik, Fakultas Ilmu Sosial dan Ilmu Politik \\ Universitas Sumatera Utara, Indonesia
}

Diterima Maret 2018; Disetujui Mei 2018; Dipublikasikan Juli 2018

Studi ini adalah studi tentang kemenangan partai lokal dengan studi kasus kemenangan Partai Aceh pada pemilihan legislatif di Kabupaten Aceh Tamiang 2009. Fokusnya membahas tentang mengapa Partai Aceh (PA) dapat memenangkan Pemilu legislatif di Kabupaten Aceh Tamiang 2009 - Metode yang digunakan adalah metode diskriptif-kualitatif, penelitian ditekankan pada memberikan gambaran secara objektif tentang keadaan yang sebenarnya dari objek yang diteliti. Akan tetapi guna mendapatkan manfaat yang lebih luas dalam penelitian ini, disamping fakta juga pemberian interprestasi-interprestasi yang kuat. Dengan teknik pengumpulan data wawancara dan dokumentasi dan teknik analisis data menggunakan analisis deskriptif. Temuan studi ini antara lain terdapat empat hal yang menjadi faktor kemenangan Partai Aceh pada Pemilu 2009. Pertama, faktor strategi politik; Kedua, adanya mesin politik yang solid; Ketiga, budaya politik masyarakat Aceh Tamiang; Keempat, atmosfir politik. Kemudian selain itu juga terdapat empat hal menjadi faktor-faktor penghambat yang dialami Partai Aceh pada Pemilu 2009. Pertama, faktor pendanaan; Kedua, adanya intimidasi; Ketiga, infrastruktur partai; Keempat, quota 30\% Caleg Perempuan.

Kata Kunci: Partai Lokal, Partai Aceh, Pemilihan Legislatif, Pemilu, Aceh Tamiang.

\begin{abstract}
Abstrak
This study is a study of the victory of local parties with a case study of Aceh Party's victory in legislative elections in Aceh Tamiang District 2009. The focus discusses why the Aceh Party (PA) can win the legislative elections in Aceh Tamiang District 2009. The method used is descriptive-qualitative method, The research are emphasized on giving an objective picture about the actual state of the object under study. However, in order to obtain broader benefits in this study, in addition to the fact also the provision of strong interpretations. With the technique of collecting interview data and documentation and data analysis techniques using descriptive analysis. The findings of this study include four things that are the factors winning the Aceh Party in the 2009 Election. First, the factors of political strategy; Secondly, there is a solid political machine; Third, the political culture of the people of Aceh Tamiang; Fourth, the political atmosphere. Furthermore, there were also four things to be the inhibiting factors experienced by the Aceh Party in the 2009 Election. Firstly, the funding factor; Secondly, the existence of intimidation; Third, party infrastructure; Fourth, 30\% quota of female candidates.

Password: Local Party, Partai Aceh, Election, Legislativ Election, Aceh Tamiang.
\end{abstract}

How to cite: Karya, A (2018), Kemenangan Partai Partai Aceh pada Pemilihan Legeslatif 2009 di Kabupaten Aceh Tamiang 2009. Politeia: Jurnal Ilmu Politik, 10 (2) (2018): 44-51.

\footnotetext{
*Corresponding author:

E-mail: abdikaryap@gmail.com
} 


\section{PENDAHULUAN}

Penandatangan

(Memorendum Of Anderstanding) antara pemerintahan Indonesia dan Gerakan Aceh Merdeka (GAM) 15 Agustus 2005 di Helsinki Finlandia merupakan awal dari harapan baru bagi seluruh masyarakat Aceh akan hidup yang lebih baik, aman dan damai. Pasca penandatangan MOU tersebut Aceh diberikan wewenang untuk dapat hidup mandiri, baik itu dibidang ekonomi maupun politik dan hukum. Secara politik Aceh diberikan wewenang untuk mendirikan partai politik lokal yang tercantum dalam MOU yakni :

Poin 1.2.1 sesegera mungkin, tetapi tidak lebih dari satu tahun sejak penandatanganan nota kesepahaman ini, pemerintah RI menyepakati dan akan memfasilitasi pembentukan partai-partai politik yang berbasis di Aceh yang memenuhi persyaratan nasional. Memahami aspirasi rakyat Aceh untuk partai-partai politik lokal, pemerintah RI dalam tempo satu tahun, atau paling lambat 18 bulan sejak penandatangan nota kesepahaman ini, akan menciptakan kondisi politik dan hukum untuk pendirian partai politik lokal di Aceh dengan berkonsultasi dengan DPR. Pelaksanaan kesepahaman ini yang tepat akan memberi sumbangan positif bagi maksud tersebut (Nota Kesepahaman antara Pemerintah Republik Indonesia dan Gerakan Aceh Merdeka, 2005).

Poin 1.2.3 Pemilihan lokal yang bebas dan adil akan diselenggarakan di bawah Undang-undang baru tentang penyeleggaraan pemerintahaan di Aceh untuk memiliki kepala pemerintahan Aceh dan pejabat terpilih lainnya pada bulan april 2006 serta untuk memilih anggota legeslatif pada tahun 2009.

Hasil dari nota kesepahaman antara Gerakan Aceh Merdeka (GAM) dan Republik Indonesia (RI) ini pemerintah mengeluarkan UndangUndang Nomor 11 tahun 2006 tentang pemerintahan Aceh dan peraturan pemerintah Nomor 20 Tahun 2007 mengenai partai politik. Hal ini yang kemudian menjadi landasan awal terbentuknya partai lokal di Aceh.

Kemenangan Partai Aceh (PA) dalam Pemilu 2009 menggambarkan sebagai jalan tengah respon atas perdamaian yang baru disepakati antara RI-GAM di Helsinki. Kemenangan Partai Aceh di tingkat Provinsi Aceh sangat luar biasa dengan meraih sekitar $(1,007,173$ suara $(43,9 \%)$ (KPU.go.id, 2010).

Sedangkan untuk wilayah Aceh Tamiang, Partai Aceh meskipun tidak mendominasi suara secara mutlak, Partai Aceh unggul dengan perolehan 29.228 suara. Hal ini menandakan bahwa Partai Aceh di kabupaten Aceh Tamiang memperoleh suara terbanyak dari partai lain, baik itu partai Nasional maupun Partai lokal lainnya sebagai pesaing utama Partai Aceh (PA), seperti Partai Aceh Aman Sejahtera, Partai Bersatu Aceh, Partai Daulat Aceh, Partai Rakyat Aceh dan Partai Suara Independen Rakyat Aceh.

Studi ini membahas mengenai kemenangan partai lokal yaitu Partai Aceh (PA) pada Pemilu legislatif di Kabupaten Aceh Tamiang 2009. Penelitian ini bertujuan untuk mengetahui faktor yang menentukan kemenangan Partai Aceh pada pemilu legislatif 2009 dan juga untuk mengetahui hambatan-hambatan yang dialami Partai Aceh (PA) dalam pemilahan legislatif 2009. 
Partai politik adalah organisasi politik yang dibentuk oleh sekelompok warga Negara Republik Indonesia secara sukarela atas dasar persamaan kehendak dan cita-cita untuk memperjuangkan kepentingan anggota, masyarakat, bangsa, dan Negara melalui pemilihan umum (UU No 2 Tahun 2008). Menurut Meriam Budiarjo: Partai politik adalah suatu kelompok yang terorganisir yang anggotanya mempunyai orientasi, nilai-nilai dan cita-cita yang sama. Tujuan kelompok ini adalah memperoleh kekuasaan politik dan merebut kedudukan politik melalui cara yang konstitusional untuk melaksanakan kebijaksanaan yang mereka miliki. Menurut Carl J. Friedrich: Partai politik adalah sekelompok manusia yang terorganisir secra stabil dengan tujuan merebut atau mempertahankan penguasaan terhadap pemerintahan bagi pimpinan partainya dan berdasarkan penguasaan ini memberikan kepada anggota partainya kemanfaatan yang bersifat idiil maupun materiil (A. Rahman H.I, 2007).

Berdasarkan

Peraturan

Pemerintah Nomor 20 Tahun 2007 tentang partai politik lokal bahwa yang dimaksud dengan partai politik lokal adalah organisasi politik yang dibentuk oleh sekelompok warga Negara Indonesia yang berdomisili di Aceh secara sukarela atas dasar persamaan kehendak dan cita-cita yang memperjuangkan kepentingan anggota, masyarakat, bangsa, dan Negara melalui pemilihan anggota DPRA/DPRK, Gubernur/Wakil Gubernur, Bupati/Wakil Bupati, dan
Walikota/Wakil Walikota (PP tentang Parpol Lokal No 20 Tahun 2007).

Partai Aceh berdiri ada tanggal 4 juni 2007 di Banda Aceh dengan ketua umum Muzakkir Manaf dan sekjen Muhammad Yahya. Partai Aceh memiliki misi mentransformasikan dan membangun wawasan berfikir masyarakat Aceh dari citra revolusi party menjadi citra development party dalam tatanan transparansi untuk kemakmuran hidup rakyat Aceh khususnya dan bangsa Indonesia umumnya.

Membahas mengenai partai politik ini tidak terlepas dari yang namanya "strategi politik". Strategi politik merupakan teknik, cara, atau strategi yang digunakan untuk mewujudkan suatu cita-cita politik, strategi politik sangat penting bagi setiap partai politik, tanpa adanya strategi politik maka perubahan jangka panjang sama sekali tidak akan terwujud. Perencanaan strategi suatu proses dan perubahan politik merupakan analisis yang gamblang dari keadaan kekuasaan, sebuah gambaran yang jelas mengenai tujuan akhir yang ingin dicapai, dan juga segala kekuasaan untuk mencapai tujuan tersebut (Peter Schoder, 2003).

Dalam rangka memenangkan pemilihan umum setiap partai politik harus memiliki strategi dan ini juga merupakan bagian dari grand strategi partai politik, yaitu yang disebut dengan strategi politik. Sebuah bentuk strategi politik yang khusus adalah strategi pemilihan umum. Dalam strategi pemilihan umum, yang terpenting disini adalah memperoleh kemenangan dan kekuasaan sebanyak mungkin pengaruh dengan cara memperoleh hasil yang baik dalam 
pemilihan umum, sehingga politik dapat diwujudkan dalam suatu perubahan dalam masyarakat.

Persaingan dalam memperoleh suara sebanyak-banyaknya dalam pemilihan umum, untuk menarik simpatik pemilih harus direncanakan dengan hati-hati, di disain dengan sebaik mungkin dan membutuhkan apa yang disebut dengan "strategi"(Firmanzah, 2007). Strategi pemilihan umum yang digunakan untuk memperoleh kekusaan seringkali dipandang suatu hal yang buruk. Padahal strategi ini digunakan dengan tujuan untuk menyampaikan dan menawarkan konsep-konsep dari partai politik.

\section{METODE PENELITIAN}

Jenis penelitian yang digunakan dalam penelitian ini adalah kualitatif, metodologi kualitatif sebagai prosedur penelitian yang menghasilkan data deskriftif berupa kata-kata tertulis atau tulisan dari orang-orang dan perilaku yang diamati.

Penelitian deskriftif merupakan suatu penelitian yang mengungkapkan suatu masalah atas keadaan atau fenomena yang terjadi, sehingga sekedar mengungkapkan fakta (fack finding). Hasil penelitian ditekankan pada memberikan gambaran secara objektif tentang keadaan yang sebenarnya dari objek yang diteliti. Akan tetapi guna mendapatkan manfaat yang lebih luas dalam penelitian ini, disamping fakta juga pemberian interprestasiinterprestasi yang kuat (Nawawi, 1995).

\section{HASIL DAN PEMBAHASAN}

Pemilihan umum legeslatif 2009 merupakan pemilu pertama kali yang di ikuti oleh Partai Lokal di Aceh. Keikutsertaan Partai lokal menjadi salah satu sejarah baru atas berkembangnya demokrasi di Indonesia. Pemilan Umum Legeslatif yang di selenggarkan pada Tanggal 09 April 2009, mencatat sejarah baru bagi pertpolitikan di Indonesia, partai lokal ikut serta berkompetisi dengan partai Nasional dalam pemilihan calon legislatif.

Kemenangan Partai Aceh (PA) berlanjut hingga hanya menyisahkan satu kursi untuk Partai Daulat Aceh (PDA) sebagai pesaing Partai Aceh ditingkat lokal dari lima Partai lokal lain yang berkompetisi pada pemilihan umum legeslatif 2009.

Berikut tabel jumlah Anggota Partai Politik Terpilih untuk Dewan Perwakilan Rakyat Aceh pada Pimilu 2009 (KIP Prov NAD).

Tabel 2 Daftar Terpilih Anggota Dewan Perwakilan Rakyat Aceh (DPRA)Pemilihan Umum 2009.

Kabupaten Aceh Tamiang terdiri dari 12 Kecamatan dibagi 3 daerah pemilihan, dengan jumlah pemilih sebanyak 165, 520 suara. Pada pemilihan Umum Legeslatif 2009 Partai Aceh mendapat jumlah kursi terbanyak mengalahkan Partai-partai lain baik itu partai nasional maupun partai lokal. Partai Aceh (PA) memperoleh 8 kursi di Dewan Perwakilan Rakyat Kabupaten (DPRK) dari 30 jumlah kursi yang ada.

Di sini penulis memaparkan dan menganalisis beberapa faktor yang menentukan kemenangan Partai Aceh dalam pemilihan legeslatif. Data yang diperoleh dari hasil wawancara 
penulis dengan tokoh dan pengurus DPW PA Kabupaten Aceh Tamiang.

Adapun beberapa faktor tersebut adalah (Ahmad, dkk, 2010):

Pertama, Strategi Partai Aceh yang berbeda dengan Partai Nasional dan Partai lokal lainnya yang masih menggunakan cara-cara konvensional. Partai Aceh melakukan strategi politik yang sederhana, murah dan efektif sementara stretegi politik ini dianggap populis di mata masyarakat Aceh. Misalkan isu politik yang diusung yaitu $\mathrm{MuO}$ Helsinki sebagai masa depan politik masyarakat Aceh. Sebagaimana MoU Helsinki adalah urat nadi politik orang Aceh sekarang. Kalau MoU gagal diimplementasikan berarti Aceh akan mengalami kehancuran baru.

Partai Aceh melakukan Political Powering ( pemberdayaan politik) dari grassroot sampai elit Aceh di level provinsi. Partai Aceh juga melakukan rekrutmen politik yang cukup representative sabagai strategi politik, caleg-caleg PA di rekrut dari level terbawah dalam masyarakat dengan membentuk tim sembilan, sistem ini merupakan sitem yang dikenal dengan konvensi politik ala PA, disisi lain, strategi PA dalam menyampaikan visi dan misi politik serta program kerja menggunakan metode pendidikan politik (political education) yang tepat di masyarakat. Pendekatan media dan elektrronik juga digunakan oleh PA, menunjukkan angka yang representative yang berimbang antara kelompok perempuan dan kelompok laki-laki, kelompok mantan kombatan GAM dan kelompok masyarakat sipil, dari figur yang populis hingga figur yang kurang di kenal masyarakat, keterwakilan ini sangat penting dalam menentukan pilihan politik masyarakat Aceh.

Berikut strategi Partai Aceh dalam memenangkan Pemilihan Umum Legeslatif di Kabupaten Aceh Tamiang yaitu diantaranya: Penguatan Internal Partai Aceh dengan cara-cara sebagai berikut, fokus pada konsolidasi; direct selling (turun dan terjun langsung ke lapangan dengan program yang bersifat "door to door"); sosialisasi menyeluruh (dengan melibatkan tokoh-tokoh agama dan kader partai).

Kedua, Mesin Politik yang Solid. Partai Aceh memiliki mesin politik yang solid dan kuat di masyarakat dari level gampong (setingkat dengan kelurahan) sampai provinsi. Berikut mesin politik Partai Aceh :

1. Anggota Partai

Anggota partai merupakan sarat dari terbentuknya partai itu sendiri, semakin banyak anggota partai yang dimiliki setiap partai politik menunjukkan semakin solid partai tersebut. Sebagai partai baru yang lahir dari MoU Helsinki DPW PA Aceh tamiang mendapat antusiasme dari masyarakat Aceh Tamaiang terhitung dari jumlah kartu anggota yang diterbitkan DPW PA Aceh Tamiang sebanyak 70.000 anggota, hal ini menunjukan ke solidan PA dalam mengiti Pemilu Legeslatif 2009.

2. Komite Peralihan Aceh (KPA) KPA merupakan mantan kombatan gerakan separatis di Aceh yaitu GAM (Gerakan Aceh Merdeka), sebagai bahagian dari pemerintahan daerah yang diberikan secara khusus bagi mantan GAM. Akhirnya KPA membentuk partai politik lokal yaitu Partai Aceh sebagai kendaraan politik 
untuk menjalankan poin-poin dari MoU hilsinki, bila mana kendaraan politik tersebut menguasai kursi legeslatif, baik itu di tingkat Provinsi maupun di tingkat Kabupaten, maka tujuan dari KPA untuk menjalankan poin-poin MoU Helsinki tersebut tercapai, dengan menunjuk wakilwakilnya di parlemen.

Pada Pemilihan Umum Legeslatif 2009 ini, mesin politik Partai Aceh, KPA berjalan dengan maksimal, dengan adanya Panglima sagoe KPA di setiap gampoeng/ desa, memudahkan PA untuk mengenalkan para caleg-caleg, dengan menyebarkan photo-photo caleg tersebut di agoe-sagoe, dengan cara ini memudahkan para caleg yang tidak menjangkau daerah pemilihannya, sehingga caleg tersebut mendapat suara di daerah yang tidak terjangkaunya, berkat adanya panglima sagoe tersebut. Keberadaan panglima sagoe ini dianggap masyarakat sebagai figur ureng chik gampoeng/ orang tua desa, sehingga perannya sangat penting di desa.

3. Ulama Kharismatik

Partai Aceh memiliki mesin politik dari ulama. Ulama merupakan orang yang paling di hargai oleh masyarakat Aceh, dalam kebudayaan Aceh sendiri ulama mendapat posisi yang tinggi dalam struktur masyarakat, sehingga dalam hal ini Partai Aceh melakukan pendekatan kepada ulama bukan untuk menjadi kader partai melainkan untuk menjadi simpatisan partai.

Pada pemilihan umum legeslatif 2009 DPW PA Aceh Tamiang mendapat dukungan dari ulama. Di setiap kampanye yang dilakukan oleh PA mengikut sertakan para ulama, dengan andanya ulama tersebut mendapat respon yang baik dari masyarakat, hal ini dapat dilihat dari kampanye yang dilakukan PA pada tanggal 17 maret 2009 yang di selenggarakan di Karang Baru, pada kampanye tersebut PA berhasil mengumpulkan massa sebanyak 40.000 massa dengan suasana kondusif, dan tidak melanggar ketentuan dari Badan Pengawas Pemilu (Bawaslu).

Ketiga, Budaya Politik, masyarakat Aceh dalam hal ini Kabupaten Aceh Taming menunjukkan sikap partisipasi politik yang tinggi, pada Pemilihan Umum Legeslatif 2009 dapat dilihat dari jumlah pemilih 165.520 suara, hanya 40.588 atau $24,52 \%$ suara yang tidak membirikan partisipasi pada pemilihan legeslatif, artinya dapat disimpulkan bahwa tinggat partisispasi masyarakat Aceh Tamiang sangat tinggi.

Keempat, Atmosfir Politik yang mempengaruhi kemenangan Partai Aceh, artinya secara konstlasi politik lokal, Partai Aceh Menunjukkan sebagai kekuatan politik baru yang dianggap dapat membawa perubahan politik dan ekonomi Aceh kedepan. Atmosfir politik ini sangat mempengaruhi masyarakat untuk melakukan perubahan sikap politik dari pilihan politik pada partai Nasional kepada partai lokal. Namun, arahan pilihan masyrakat Aceh Tamiang Lebih tinggi kepada Partai Lokal, Masyarakat melihat bahwa pemilu 2009 di Aceh sangatlah penting dalam menentukan masa depan Aceh, implementasi MoU Helsinki sangat penting untuk dilakukan Partai Aceh dibandingkan partai lainnya yang dianggap masyarakat tidak memiliki legetimasi 
dalam mengimplemintasikan $\mathrm{MoU}$ Helsinki jika memenangkan pemilu di Parlemen.

Munculnya proses demokratisasi yang berkembang di Aceh melalui lembaga internasional serta pengalaman Negara-negara yang baru mengalami perdamain di dunia, pada akhirnya secara mayoritas memenangkan pemilu pertama pasca $\mathrm{MoU}$ atau perjanjian damai yang telah disepakati.

\section{Hambatan-Hambatan Yang Dialami Partai Aceh.}

Pertama, Pendanaan pada Pemiliahan Umum Legeslatif 2009 DPW PA Aceh Tamiang mendapat hambatan yaitu dari sumber pendanaan yang minim, selain dari dana peserta pemilu yang diberikan KPU sebagai penyelenggara, Partai Aceh hanya memperoleh dana dari swadaya dari partisan partai dan kader partai. Sehingga proses sosialisasi partai serta kampenye yang dilakukan tidak maksimal dan efesien.

Kedua, Adanya Intimidasi. Pada awal pembentukan Partai Aceh muncul kecurigaan bahwa perjuangan dari GAM di lanjutkan dalam bentuk Partai Politik hal ini dapat dilihat pada Pemilihan Umum Legeslatif 2009 Partai Aceh merupakan partai yang sering diidentifikasikan sebagai pelaku pengrusakan, karena Partai Aceh identik dengan GAM, sehingga munculah tuduhan-tuduhan seperti pengerusakan, pembakaran, kemudian ancaman apabila Partai Aceh tidak menang akan terjadinya konflik kembali di Aceh, yang dilakukan lawan politik Partai Aceh (Budi Santoso dan Upah, 2010).

\section{Ketiga, Infrastruktur partai.} Sebagai partai baru, infrastruktur Partai Aceh seperti AD/ART dan kantor-kantor partai belum selengkap dan sesempurna seperti partai nasional yang ada di Indonesia. Hal ini yang kemudaian menjadi hambatan atas sosialisasi yang dilakukan oleh Partai Aceh, kendatipun demikian PA memiliki mesin politik yang terorganisir di setiap gampoeng/ desa.

\section{Keempat, Quota $30 \%$ Caleg}

Perempuan. Pada Pemilihan Umum Legeslatif 2009 ini DPW PA Aceh Taminag tidak dapat memenuhi qoata $30 \%$ caleg untuk perempuan, yang merupakan ketentuan yang di keluarkan Komisi Pemilihan Umum bagi setiap partai politik. Tidak terpenuhinya qota tersebut, kemudian menjadi hambatan bagi DPW PA Aceh Tamiang, sehingga DPW PA Aceh Tamiang melakukan tindakan dengan mengeluarkan surat rujukan kepada Komisi Independen Pemilu (KIP) Aceh. Qoata caleg perempuan untuk Partai Aceh hanyan $20 \%$.

\section{SIMPULAN}

MoU (Memorendum of Understanding) antara Republik Indonesia dan Gerakan Aceh Merdeka 15 Agustus 2005 di Helsinki Finlandia, merupakan wujud cikal bakal terbentuknya Partai lokal di Aceh yang kemudian tercantum dalam poin-poin MoU dari poin 1.2.1 sampai 1.2.3 tentang partisipasi politik Aceh, serta adanya Undang-undang Nomor 11 Tahun 2006 dan Peraturan Pemerintah Nomor 20 Tahun 2007 yang mengesahkan terbentuknya partai politik lokal di Nangroe Aceh Darussalam. Kemudian terbentuklah 
enam Partai lokal diantranya Partai Aceh. Pada Pemilihan Umum Legeslatif 2009 Partai Aceh memenangkan Pemilihan Umum Legeslatif 2009 dengan perolehan suara 334.337 suara atau $43,09 \%$ suara, untuk kursi di Dewan Perwakilan Rakyat Aceh (DPRA). Partai Aceh juga menang di kabupaten Aceh Tamiang dengan perolehan suara 29.288 suara dengan perolehan kursi di Dewan Perwakilan Rakyat kabupaten (DPRK) sebanyak 8 kursi.

Ada beberapa faktor kemenagan Partai Aceh pada pemilihan umum legeslatif 2009 yaitu, strategi politik, adanya mesin politik yang solid, budaya politik dan atmosfir politik. Ke empat hal ini yang dilakukan oleh DPW PA Aceh Tamiang dalam upaya memenangkan pemilihan legeslatif 2009. Yang membedakan Partai Aceh dengan Partai Nasional dan Partai lokal lainya adalah isu. Partai Aceh mengusung isu "Partai Aceh adalah partai penurus dari poin-poin $\mathrm{MoU}$ Helsinksi", sebagai partai yang terbentuk dari MoU Helsinki dan partai yang di bentuk oleh mantan kombatan GAM (Gerakan Aceh Merdeka) Partai Aceh yang memiliki legitimasi untuk meneruskan poinpoin dari MoU Helsinki ini. MoU
Helsinki merupakan harapan baru bagi masyarakat Aceh pasca konflik berkepanjangan, sehingga masyarakat Aceh Tamiang khususnya memberi harapan pada Partai Aceh dengan memilih Partai ini pada pemilihan Umum Legeslatif 2009 untuk duduk di Dewan Perwakilan Daerah sebagai wakil mereka di pemerintahan daerah, dengan harapan adanya perubahan yang lebih baik.

\section{DAFTAR PUSTAKA}

Nawawi, Hadari. (1995) Penelitian Bidang Sosial. Yogyakarta: Gajah Mada University Press

Rahman, A. H.I. (2007). Sistem Politik Indonesia. Yogyakarta: Graha Ilmu

Schoder, Peter. (2003). Strategi Politik. Jakarta: Friderich Naumun Stifung

Firmanzah. (2007). Marketing Politik Antara Pemahaman dan Realita. Jakarta: Yayasan Obor Indonesia

Moleung, Lex J. (1994). Metodologi Penelitian Kualitatif. Bandung: PT. Remaja Rodakarya

\section{Sumber lain}

Nota Kesepahaman antara Pemerintah Republik Indonesia dan Gerakan Aceh Merdeka 15 Agustus 2005

www.KPU.go.id diakses pada tanggal 3 januari 2010

Komisi Independen Pemilihan Provinsi Nanggroe Aceh Darussalam 